\title{
Her-2/Neu, Estrogen and Progesterone Receptor Expression In WHO Grade I Meningiomas
}

\author{
WHO Grade I Meningiomlarda Her-2/Neu, Östrojen ve Progesteron Reseptör Ekspresyonu
}

\author{
Nilüfer ONAK KANDEMIR, Aylin EGE GÜL, ${ }^{1}$ Banu DOĞAN GÜN, \\ Nimet KARADAYI, ${ }^{1}$ Gamze YURDAKAN, Şükrü Oğuz ÖZDAMAR \\ Department of Pathology, Medical Faculty of Zonguldak Karaelmas University, Zonguldak; \\ ${ }^{1}$ Department of Pathology, Dr. Lütfi Kırdar Training and Research Hospital, İstanbul
}

Submitted / Başvuru tarihi: 27.11.2008 Accepted/Kabul tarihi: 02.04.2009

\begin{abstract}
Objectives: Meningiomas are generally benign central nervous system neoplasms, which frequently express progesterone receptor (PR) and rarely express the estrogen receptor (ER). The significance of Her-2/neu expression in meningiomas is unclear. We evaluated the correlation with Her-2/neu, PR, ER expressions and clinicopathologic parameters in World Health Organization (WHO) Grade I meningiomas.
\end{abstract}

Patients and Methods: In total, 53 cases of meningiomas were included in this study. Formaline-fixed, paraffin-embedded tissue sections were immunostained for Her-2/neu, PR and ER.

Results: Whereas $27(50.9 \%)$ of meningiomas were positive for PR, no reaction was determined for ER. Her-2/neu overexpression was observed in $12(22.6 \%)$ cases. There was positive correlation between Her-2/ neu and PR expressions $(p=0.015)$. Her-2/neu expression was frequently seen in meningothelial type $(p=0.03)$. There were no correlations with Her-2/neu, ER, PR and other clinicopathologic parameters.

Conclusion: The results of our study show that despite there being PR expression at a high rate in grade I meningiomas, ER expression is a rare finding. Moreover, Her-2/neu expression has been detected more often in the PR positive and meningothelial type.

Key words: Her-2/neu; progesterone receptor; estrogen receptor; meningioma.
Amaç: Meningiomlar genellikle benign davranış gösteren, sıklıkla progesteron reseptörü (PR), seyrek olarak da östrojen reseptörü (ER) eksprese eden santral sinir sistemi neoplazileridir. Meningiomlarda Her-2/neu ekspresyonunun önemi henüz aydınlatılamamıştır. Bu çalışmada, WHO grade I meningiomlarda Her-2/neu, PR ve ER ekspresyonları ile klinikopatolojik parametreler arasındaki ilişki araştırıldı.

Hastalar ve Yöntemler: Çalışmaya toplam 53 meningiom olgusu dahil edildi. Formalinde fikse edilen, parafine gömülmüş doku kesitlerinde Her-2/neu, PR ve ER immünboyaması gerçekleştirildi.

Bulgular: Meningiomların 27'sinde (\%50.9) PR pozitivitesi saptanırken, ER ile reaksiyon saptanmadı. On iki olguda (\%22.6) Her-2/neu overekspresyonu belirlendi. Her-2/neu ile PR ekspresyonu arasında pozitif korelasyon saptandı $(p=0.015)$. Her-2/neu ekspresyonu meningotelyal tipte daha sık olarak izlendi $(p=0.03)$. Her-2/neu, $\mathrm{ER}$, PR ve diğer klinikopatolojik parametreler arasında ilişki saptanmadı.

Sonuç: Çalışmamızın sonuçları grade I meningiomlarda PR ekspresyonunun sıklığına karşın, ER ekspresyonunun nadir bir bulgu olduğunu gösterdi. Ek olarak, Her-2/ neu ekspresyonunun PR pozitif ve meningotelyal tipte daha sık görüldüğü saptandı.

Anahtar sözcükler: Her-2/neu; progesteron reseptör; östrojen reseptör; meningiom.

\footnotetext{
Presented at the 21st European Congress of Pathology, September 08-13, 2007, İstanbul, Turkey (21. Avrupa Patoloji Kongresi'nde sunulmuştur, 8-13 Eylül 2007, İstanbul).

Correspondence (Illetişim adresi): Dr. Nilüfer Onak Kandemir. Zonguldak Karaelmas Üniversitesi Tıp Fakültesi Patoloji Anabilim Dalı, 67600 Zonguldak, Türkiye. Tel: 0372 - 2612001 Fax (Faks): 0372 - 2610155 e-mail (e-posta): niluferkandemir@yahoo.com

(c) Trakya Üniversitesi Tıp Fakültesi Dergisi. Ekin Tıbbi Yayıncılık tarafından basılımışır. Her hakkı sakııdır.

(c) Medical Journal of Trakya University. Published by Ekin Medical Publishing. All rights reserved.
} 
Meningiomas arise from the meningothelial cells of arachnoid granulations and are one of the most common tumors of the central nervous system. Ninety percent of meningiomas are classified as histologically benign and correspond to grade I of the World Health Organization (WHO) classification for tumors of the nervous system. The standard treatment for meningiomas is surgical resection, with additional radiation therapy when necessary. Meningiomas recur in more than $20 \%$ of cases and are sometimes inoperable because of their relatively inaccessible locations. ${ }^{[1]}$ Morphological and biopathological parameters such as histological grade, histological sub-type, high proliferative index, and brain invasion have been proposed to have prognostic value. ${ }^{[2]}$ Given the variable behavior of meningiomas, even all of these factors in concert may be inadequate for determining the course of the disease. The preponderance of progesterone receptors (PRs) and the scarcity of estrogen receptors (ERs) in meningiomas are well known. The expression of PRs may relate to tumour grade, recurrence, and low proliferative index. ${ }^{[3-7]}$ The role of ERs in meningiomas remains unclear. ${ }^{[4-6]}$ The oncogene Her-2/neu, the second member of the epidermal growth factor receptor family, is a well-known prognostic factor in various human tumors such as breast carcinoma. ${ }^{[8,9]}$ However, the significance of Her-2/neu expression in meningiomas is currently unknown. ${ }^{[10-16]}$

In the present study, we analyzed the immunohistochemical expression of the PR, ER, and Her-2/neu in WHO grade I meningiomas. In addition, we related the expression profiles of these factors to clinicopathological parameters such as age, gender, tumour size, brain and dura invasion, histological subtype, and proliferative index.

\section{PATIENTS AND METHODS}

\section{Clinical Data}

Fifty-three primary benign intracranial meningioma (WHO grade I) cases were included in this retrospective study. Of these, 32 were diagnosed in the Department of Pathology, Zonguldak Karaelmas University School of Medicine and 21 were diagnosed in the Department of Pathology in Dr. Lütfi Kırdar Training and Research Hospital between 2003 and 2008. Clinical information was obtained for all cases.

\section{Histopathological Examination}

Meningioma tissue samples were routinely fixed in formalin and embedded in paraffin. Sections $(5 \mu \mathrm{m})$ were stained with hematoxylin and eosin for histological examination. The slides were reviewed for histological subtyping and grading according to the WHO 2007 classification. ${ }^{[1]}$ In each case, the two most representative sections were selected for immunohistochemical staining. Normal arachnoidal tissues obtained from autopsy cases were also immunostained in parallel.

\section{Immunohistochemical Staining}

Immunohistochemical staining was performed on 4- $\mu \mathrm{m}$-thick, formalin-fixed, paraffin-embedded tissue sections using a streptavidin-biotin-peroxidase technique (BSA-DAB). To enhance staining, heat-induced epitope retrieval was performed. Primary antibodies against the ER (clone 6F11; dilution 1:150; Novocastra, Newcastle, UK), PR (Clone 1294; dilution 1:150; Dako, Carpinteria, CA, US), Her-2/neu (clone; CB11; dilution 1:50; Diagnostic BioSystems, CA, US), and Ki67 (clone MIB-1; dilution 1:200, Dako, Carpinteria, CA, US) were used.

\section{Controls and Immunostaining Criteria}

All nuclear stainings were positive for Ki67. The mitotic index (MI) was determined by summing the total number of mitotic figures observed in the 10 high-power fields $(\times 400)$ that contained the highest number of mitosing cells.

Steroid receptor expression levels in each sample were semi-quantitatively evaluated. The grades were defined as follows: $0, \leq 1 \%$ positive cells; $1,2-10 \%$ positive cells; $2+$, $11-50 \%$ positive cells; and $3+,>50 \%$ positive cells. Cells with values greater than $1 \%$ were considered to be positive for PR or ER. Her-2/neu expression in each sample was also semi-quantitatively evaluated, as follows: 0 , no staining; $1+$, faint and incomplete membranous pattern; $2+$, moderate and complete membranous pattern; and 3+, strong membranous pattern. An immunohistochemistry score of $2+$ or greater was considered as Her-2/neu overexpression. Appropriate positive (breast carcinoma for PR, ER and Her-2/neu; normal tonsil tissue for Ki67) and negative controls (omitted primary antibody) were evaluated simultaneously in all cases.

\section{Statistical Analysis}

The categorical and categorized variables entered into the analysis were the patient's gender, histological subtype, tumour grade, presence of meningeal/brain invasion, and PR, ER, Her-2/neu, and Ki67 expression. Differences between groups were examined using the MannWhitney U test, chi-square test and Spearman's rank test. Calculations were performed with SPSS for Windows, version 11.0 (SPSS, Inc., Chicago, IL, US). Differences were considered statistically significant at $\mathrm{p}<0.05$.

\section{RESULTS}

There were $34(64.2 \%)$ female and $19(35.8 \%)$ male patients, with an age range of 38-78 years (56.9 \pm 11.5$)$. Histologically, there were 28 (52.8\%) meningothelial, 12 (22.6\%) transitional, seven (13.2\%) psammomatous, and six (11.3\%) fibroblastic meningiomas (Fig. 1a-d).

Her-2/neu immunostaining was detected in $35(66 \%)$ of the 53 meningiomas examined, with Her-2/neu overexpression (immunoreactivity score $\geq 2+$ ) in $12(22.6 \%)$ cases (Fig. 2a, b). The proliferation index ranged from $0.35-8.4 \%(2.8 \pm 2.0 \%)$ (Fig. 2c). Twenty-seven meningiomas (50.9\%) were positive for PRs (Fig. 2d), whereas 

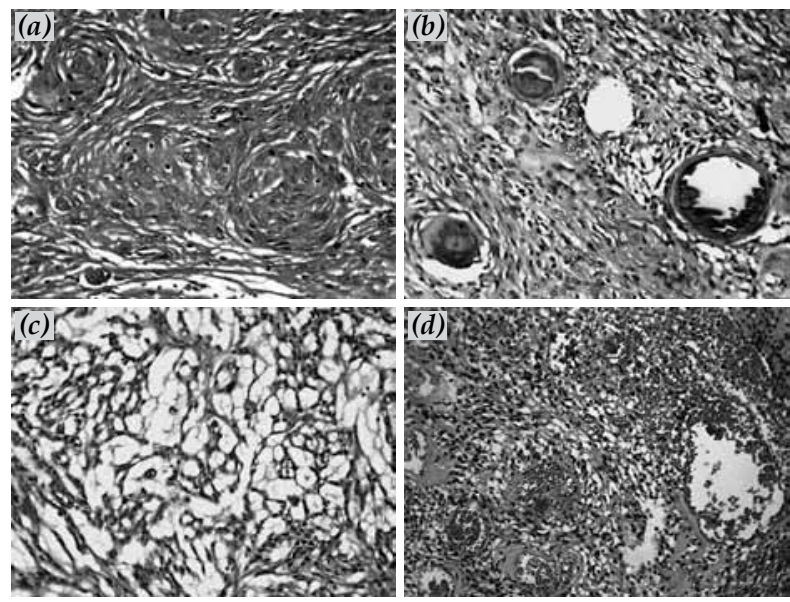

Fig. 1

Histopathological appearance of WHO grade I meningiomas. (a) Meningothelial meningioma (X60), (b) psammomatous meningioma (X40), (c) fibroblastic meningiomamicrocystic $(\mathrm{X} 80)$ and $(d)$ angiomatous (X20) component. Hemotoxylin-Eosine staining.

no staining was observed for ERs in any sample. The PR immunoreactivity was strong and distinct. Normal arachnoidal tissue was weakly positive for Her-2/neu and negative for both ER and PR. The degrees of PR and Her-2/neu immunostaining among various histological subtypes of grade I meningiomas are shown in Table 1.

There was no significant association between the proliferation index and any other clinicopathological parameter ( $p>0.05$ for each). There was a positive correlation between Her-2/neu and PR expression ( $\mathrm{r}=0.585$, $\mathrm{p}=0.015$ ), and Her- 2 / neu overexpression was frequently observed in meningothelial meningiomas $(p=0.03)$. No significant relationships were observed between Her-2/ neu, PR and ER expression and any other clinicopathological parameter ( $\mathrm{p}>0.05$ for each).

\section{DISCUSSION}

Clinical and epidemiological data reveal that meningiomas are hormone-sensitive tumors. The epidemiological similarities between meningioma and breast cancer,

Table 1. Expression of PR and Her-2/neu in meningiomas according to histological type*.

\begin{tabular}{|c|c|c|c|c|c|c|c|c|}
\hline \multirow[b]{2}{*}{ Histology } & \multicolumn{4}{|c|}{$\mathrm{PR}^{* *}$} & \multicolumn{4}{|c|}{ Her-2/neu ${ }^{* * *}$} \\
\hline & - & + & ++ & $\overline{+++}$ & - & + & ++ & $\overline{+++}$ \\
\hline Meningothelial & 13 & 7 & 5 & 3 & 5 & 16 & 4 & 3 \\
\hline Transitional & 6 & 3 & 2 & 1 & 4 & 5 & 2 & 1 \\
\hline Psammomatous & 3 & 4 & 0 & 0 & 5 & 2 & 0 & 0 \\
\hline Fibroblastic & 4 & 2 & 0 & 0 & 4 & 0 & 1 & 1 \\
\hline Total & 26 & 16 & 7 & 4 & 18 & 23 & 7 & 5 \\
\hline
\end{tabular}

* Data are given as number of cases.

** -: no positive or $<1 \%$ positive cells; $+: 2-10 \%$ positive cells; $++: 11-50 \%$ positive cells; $+++:>50 \%$ positive cells

*** -: no staining; +: faint, incomplete membranous pattern; ++: moderate, complete membranous pattern; +++: strong membranous pattern.

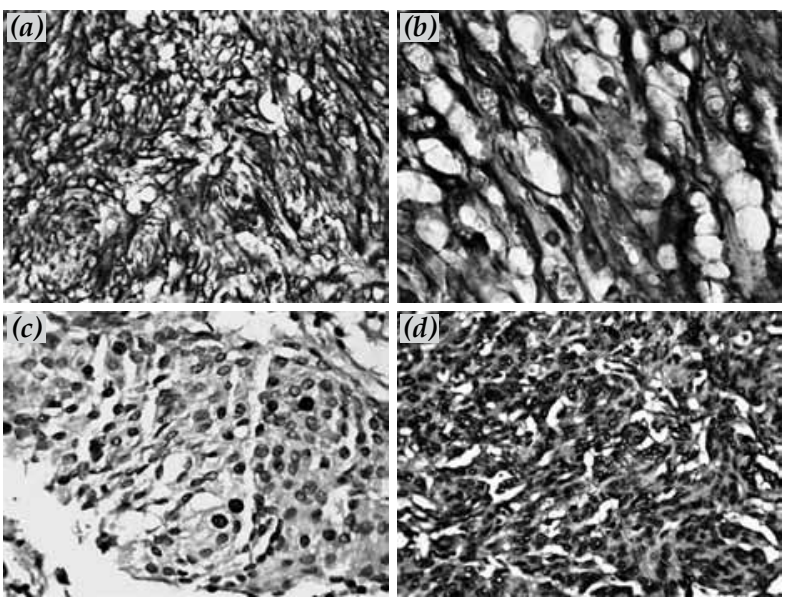

Fig. 2. Immunohistochemical stains for Her-2/neu; (a) X60, (b) X120, (c) Ki67 (X80) and (d) PR (X100) in meningothelial meningioma. $B S A-D A B$ staining.

in addition to their similar steroid hormone receptor profiles, suggest that new treatment methods used for breast cancer tumors may also be viable options for meningiomas. ${ }^{[8,9]}$ However, the role of sex steroids and Her-2/neu expression in the pathogenesis, progression, and treatment of meningiomas awaits investigation.

The presence of PRs in meningiomas has been documented in many studies, with rates of occurrence ranging from 48 to $88 \% .^{[3-7]}$ In our study, we detected PR expression in $50.9 \%$ of the cases. This occurrence rate is comparable to the results of previous studies and indicates that PR expression is frequently observed in grade I meningiomas.

A review of the literature yielded no report on the relationship between PR expression and patient age, tumour size, or histological subtype. ${ }^{[3-7]}$ Similarly, no relationship between these parameters and PR expression was detected in our study. In addition, we did not detect a statistically significant relationship between gender and PR expression. It has been reported in numerous studies that PR expression in meningiomas is more frequent in female patients. ${ }^{[3,6]}$ However, these studies included a substantial number of atypical and malignant meningiomas, which are mostly devoid of PRs and are seen more frequently in male patients. Therefore, the previously reported gender-related difference might have been the result of the particular selection criteria used in the study, which resulted in a non-homogeneous patient population.

Some researchers have noted that the lack of PR expression in WHO grade I meningiomas is associated with a high mitotic index..$^{[4,5]}$ Another group detected no relationship between PR expression and the proliferative index. ${ }^{[3]}$ We did not find a statistically significant relationship between PR expression and the proliferative index in our study.

Despite the prevalence of PR expression, ER expression in meningiomas is quite rare. Some researchers 
assert that there is no ER expression in meningiomas, ${ }^{[4,9]}$ whereas others have reported ER expression rates of $5-33 \% .{ }^{[5,6]}$ In studies employing high precision molecular techniques, the rates tended to be higher. Pravdenkova et al. ${ }^{[5]}$ advocated that positive ER expression in meningiomas is concomitant with karyotype anomalies and is an indicator of a bad prognosis. The presence of cytoplasmic ER expression has been reported in cases without nuclear ER expression. ${ }^{[6]}$ In our study, we did not detect nuclear or cytoplasmic ER expression in any of the cases. This finding is compatible with the results of other studies employing immunohistochemical methods. ${ }^{[4,6,12]}$ These results show that ER expression is detected at a lower rate than PR expression in meningiomas. These observations may be attributable to ER expression at levels too low to be detected immunohistochemically. Alternatively, it may be that PR and ER expression are independently regulated in meningiomas. However, the regulation of PR and ER expression is tightly linked in other hormonesensitive tissues (e.g., breast and ovary).

The Her-2/neu oncogene was the second member identified in the epidermal growth factor receptor family. Her-2/neu-encoded p185 protein, a receptor tyrosine kinase, is associated with multiple signal transduction pathways involved in cellular growth. ${ }^{[8]} \mathrm{Her}-2 /$ neu is a well-known prognostic factor in various tumurs such as breast carcinoma, although the significance of Her-2/ neu expression in meningiomas is unclear. ${ }^{[9-17]}$ In our study, Her-2/neu overexpression was detected in $22.6 \%$ of the cases, which is within the range of 2.5 to $67.3 \%$ reported for Her-2/neu overexpression in meningiomas. ${ }^{[9-17]}$

In a study by Loussouarn et al., ${ }^{[12]}$ Her-2/neu overexpression was more frequent in meningiomas displaying epithelial differentiation, such as meningothelial and secretory types. Durand et al. ${ }^{[13]}$ reported no relationship between Her-2/neu and histotypes. In the present study, Her-2/neu expression was also significantly higher in meningothelial meningiomas, suggesting that Her-2/ neu expression may be associated with differentiation.

No relationship has been described between Her-2/ neu overexpression and proliferative activity in previous studies, ${ }^{[9-16]}$ and our results support this finding.

Loussouarn et al. ${ }^{[12]}$ reported no relationship between Her-2/neu and PR expression. In contrast, Her-2/neu expression and PR expression were positively correlated in the present study. To the best of our knowledge, no other studies have investigated the relationship between these two parameters. Further studies are needed to provide additional reliable information on the relationship between Her-2/neu and PR expression in meningiomas.

In some studies, Her-2/neu expression was not detected in normal brain or arachnoid tissue. ${ }^{[15,16]}$ In contrast, Schlegel et al. ${ }^{[14]}$ and Potti et al ${ }^{[10,11]}$ detected Her-2 / neu in non-neoplastic arachnoid cap cells. In the current study, we also observed Her-2/neu immunoreactivity at low levels in non-neoplastic meningeal tissues. Therefore, we classified cases with $2+$ or greater Her-2/ neu expression as overexpression.

Our study demonstrated that although Her-2/neu and PR are expressed at high rates in grade I meningiomas, ER expression is rare. Moreover, Her-2/neu expression was detected more frequently in the PR-positive and meningothelial meningiomas. Studies conducted in larger patient groups may provide reliable information for formulating alternative treatment choices as well as assessing the roles of these parameters in the pathogenesis and progression of meningiomas.

\section{REFERENCES}

1. Perry A, Louis DN, Scheithauer BW, Budka H, von Deimling A. Meningiomas. In: Louis DN, Cavenee WK, Ohgaki $\mathrm{H}$, Wiestler OD, editors. WHO classification of tumours of the central nervous system. 4th ed. Lyon: WHO; 2007. p. 164-92.

2. Marosi C, Hassler M, Roessler K, Reni M, Sant M, Mazza E, et al. Meningioma. Crit Rev Oncol Hematol 2008;67:153-71.

3. Roser F, Nakamura M, Bellinzona M, Rosahl SK, Ostertag $\mathrm{H}$, Samii M. The prognostic value of progesterone receptor status in meningiomas. J Clin Pathol 2004;57:1033-7.

4. Maiuri F, De Caro Mdel B, Esposito F, Cappabianca P, Strazzullo V, Pettinato G, et al. Recurrences of meningiomas: predictive value of pathological features and hormonal and growth factors. J Neurooncol 2007;82:63-8.

5. Pravdenkova S, Al-Mefty O, Sawyer J, Husain M. Progesterone and estrogen receptors: opposing prognostic indicators in meningiomas. J Neurosurg 2006;105:163-73.

6. Konstantinidou AE, Korkolopoulou P, Mahera H, Kotsiakis X, Hranioti S, Eftychiadis C, et al. Hormone receptors in non-malignant meningiomas correlate with apoptosis, cell proliferation and recurrence-free survival. Histopathology 2003;43:280-90.

7. Blankenstein MA, Verheijen FM, Jacobs JM, Donker TH, van Duijnhoven MW, Thijssen JH. Occurrence, regulation, and significance of progesterone receptors in human meningioma. Steroids 2000;65:795-800.

8. Hung MC, Lau YK. Basic science of HER-2/neu: a review. Semin Oncol 1999;26(4 Suppl 12):51-9.

9. Custer BS, Koepsell TD, Mueller BA. The association between breast carcinoma and meningioma in women. Cancer 2002;94:1626-35.

10. Potti A, Panwalkar A, Langness E, Sholes K, Tendulkar K, Chittajalu S, et al. Role of her-2/neu overexpression and clinical features at presentation as predictive factors in meningiomas. Am J Clin Oncol 2004;27:452-6.

11. Potti A, Forseen SE, Koka VK, Pervez H, Koch M, Fraiman $\mathrm{G}$, et al. Determination of HER-2/neu overexpression and clinical predictors of survival in a cohort of 347 patients with primary malignant brain tumors. Cancer Invest 2004;22:537-44.

12. Loussouarn D, Brunon J, Avet-Loiseau H, Campone M, Mosnier JF. Prognostic value of HER2 expression in meningiomas: an immunohistochemical and fluorescence in situ hybridization study. Hum Pathol 2006;37:415-21.

13. Durand A, Champier J, Jouvet A, Labrousse F, Honnorat J, Guyotat J, et al. Expression of c-Myc, neurofibromatosis Type 2, somatostatin receptor 2 and erb-B2 in human meningiomas: relation to grades or histotypes. Clin Neuropathol 
2008;27:334-45

14. Schlegel J, Ullrich B, Stumm G, Gass P, Harwerth IM, Hynes $\mathrm{NE}$, et al. Expression of the c-erbB-2-encoded oncoprotein and progesterone receptor in human meningiomas. Acta Neuropathol 1993;86:473-9.

15. Schwechheimer K, Läufle RM, Schmahl W, Knödlseder M, Fischer H, Höfler H. Expression of neu / c-erbB-2 in human brain tumors. Hum Pathol 1994;25:772-80.
16. Andersson U, Guo D, Malmer B, Bergenheim AT, Brännström T, Hedman $\mathrm{H}$, et al. Epidermal growth factor receptor family (EGFR, ErbB2-4) in gliomas and meningiomas. Acta Neuropathol 2004;108:135-42.

17. Chozick BS, Benzil DL, Stopa EG, Pezzullo JC, Knuckey $\mathrm{NW}$, Epstein $\mathrm{MH}$, et al. Immunohistochemical evaluation of erbB-2 and p53 protein expression in benign and atypical human meningiomas. J Neurooncol 1996;27:117-26. 